\title{
Conversion of European Intellectuals to Islam: The Case of Christiaan Snouck Hurgronje alias 'Abd al-Ghaffār
}

\section{Pieter Sjoerd van Koningsveld}

In reflecting on the role learned European converts to Islam may play in intercultural communication and Islamic scholarship, it seems useful to distinguish between three main types of conversion. First, there is the permanent conversion, in which the convert acts out of free will and personal conviction and believes that he has converted for the rest of his life. In their new status, these intellectuals also may acquire completely new audiences and with them new chances for a successful intellectual career, especially if they use their talents in the service of combatting their old faith. In fact, numerous polemical and apologetic writings flew from the pens of these erudite converts who attacked their old faith or philosophy of life and defended their choice of Islam. A famous case is Fray ("Brother") Anselm of Turmeda ('Abdallāh al-Tarjumān al-Mayurqī), who authored his famous anti-Christian pamphlet Gift for the Intelligent to Confute the People of the Cross in Tunis, after his conversion to Islam in the latter half of the fourteenth century. ${ }^{1}$ In fact, this phenomenon of learned European converts producing polemical and apologetic writings continues to the present day, as is amply illustrated by the study of Salah Abdel Razaq on neo-Muslim intellectuals in the West; he writes long chapters on their contributions to Islamic polemical, anti-Western, and anti-Christian literature. ${ }^{2}$ Some of the works of these converted polemicists even enjoy distribution on a worldwide scale, in translations into the major languages of the Muslim world. There are, however, some rare exceptions to the majority of these polemical erudites. An example is Leopold Weiss, of Austrian Jewish extraction, who converted to Islam and adopted the name Muhammad Asad, then delved deeply into Arabic and Islamic sources, and ultimately developed

1 'Abdallāh al-Tarjumān al-Mayurqī, Tuhfat al-arīb fì l-radd 'alā ahl al-șalīb, ed./trans. Mikel Epalza (Madrid: Hiperión, 1994), 26-42.

2 Salah Abdel Razaq, Neo-Muslim Intellectuals in the West and Their Contributions to Islamic Thought and the Formation of Western Islam (Leuven: Peeters, 2008), Ch. 5, 229-262, and Ch. 6, 263-212.

(C) PIETER SJOERD VAN KONINGSVELD, 2016 | DOI 10.1163/9789004301979_005 This is an open access chapter distributed under the terms of the Creative Commons 
into an Islamic scholar with a wide recognition, and even translated and commented upon the Qurān. ${ }^{3}$

A second type of conversion frequently observed is forced conversion. Here, the intention of the "convert" usually is to return in due time to his/her original faith or conviction or even to continue his/her original faith or conviction without any interruption but in secret. This results in the phenomenon of a simulated or fraudulent conversion. During the period of slavery, for instance, many enslaved European Christians outwardly converted to Islam under duress. Those who were fortunate enough to escape or be ransomed usually reverted to their original faith immediately upon returning to their home countries. ${ }^{4}$

A third type of conversion to be distinguished is the conversion of convenience. This is an insincere form of conversion performed only to obtain certain interests, like a marriage, access for one's children to a confessional school, access to a certain club or place open to adherents of a particular religion. The fraudulent convert who converts out of convenience may have in mind activities such as espionage, research in the field, love relations, etc. The history of European "conversions of convenience" to Islam is promising and deserves a profound historical study. The earliest example known to the present author dates back to the year 1162, when, according to Arabic sources, two Andalusian Christians (probably Arabic speaking "Mozarabs" from Christian Spain), disguised as Muslims, attempted to dig an underground tunnel in Medina, in order to steal the bones of the Prophet Muhammad and bring these with them back to Spain. They were unmasked and executed. ${ }^{5}$ Another early example is the early sixteenth-century Italian traveler Ludovico di Varthema who as a "temporary convert" was able to provide an eyewitness report of the Prophet's Mosque in Medina with historical explanations in a language that his readers could understand; he described, for instance, Abū Bakr, Muhammad's successor buried next to him, as a "cardinal, who had the ambition to become pope."

Each of us can think of some famous examples of a more recent time, like Edward William Lane (1801-1876), who undertook research in the first half of

3 Martin Kramer, "The Road from Mecca: Muhammad Asad (born Leopold Weiss)," in The Jewish Discovery of Islam, ed. Martin Kramer (Tel Aviv: Tel Aviv University, 1999), 225-247.

4 Bartolomé Bennassar et Lucile Bennassar, Les chrétiens d'Allah. L'histoire extraordinaire des rénégats. XVIe-XVIIe siècles (Paris: Perrin, 1989).

5 For a detailed report see, among others: al-Samhūdī, Wafā l-wafā̃ bi-akhbār dār al-Muștafā, ed. Qāsim al-Sāmarrā̄ì (Mecca/Medina: Mu’assasat al-Furqān 1422/2001), 2:431-439.

6 Ludovico di Varthema, The Itinerary of Ludovico di Varthema of Bologna from 1502 to 1508 as Translated from the Original Italian Edition of 1510, by John Winter Jones, F.S.A. in 1863 for the Hakluyt Society (London: Argonaut Press, 1928), xxxiv. 
the nineteenth century into the manners and customs of the Egyptians. Wellknown travelogues of an earlier date, like those of Johann Ludwig Burckhardt (1784-1817) and Richard Francis Burton (1821-1890) could hardly have been written had they not enjoyed the advantages of temporary conversions. Less known is the example of Léon Roches (1809-1900), who would hardly have been successful in gathering fatwās in favor of the French colonial administration, had he not presented himself as a Muslim. He was called "Omar ould Roches" by the leader of the Algerian resistance against the French invasion of Algeria, Prince 'Abd al-Qādir, in 1837 after the latter had married him to a woman from his entourage and had made him his personal secretary. His mission to collect fatwās in Kairouan, Cairo, and Mecca, that authorized Muslims of Algeria to live under French domination, dates back to the early 1840 . After having completed this mission, Roches decided to enter the clergy as a priest and involve himself in the mission. After King Louis Philippe convinced Pope Gregory XVI that he urgently needed the prolonged services of Roches, he left the clergy and was reintegrated into the French army as its chief interpreter. ${ }^{7}$

The Dutch orientalist Christiaan Snouck Hurgronje (1857-1936) is a special case; he accumulated the social and political advantages of a conversion of convenience to its fullest extent, during a long period of his active life. His conversion started as a temporary one but happened to develop into a more permanent form, though it remained restricted to a segment of his network, only. Snouck's half year stay in Mecca (1884-1885) was, probably, initially conceived by him in the framework of a temporary conversion needed only for that stay. It so happened, however, that the further vicissitudes of his life incited him to revitalize his "temporary" conversion after the original date of its expiration, when, in 1889 he went to the Dutch East Indies and stayed there for sixteen years as an official advisor to the Dutch government. There he resumed his Meccan Muslim network and expanded it considerably, also founding a Muslim family with Muslim wives and Muslim children. Here we observe the origins of a double life that continued until his death in 1936. His first and by far the most extensive network were his European contacts, including many orientalists and other academics, in addition to a long list of officials of the Dutch colonial administration. The second network consisted of his Muslim contacts, including prominent religious scholars and members of the ruling class, mainly from Arabia and the Dutch East Indies. ${ }^{8}$

7 Jacques Caillé, Une mission de Léon Roches à Rabat en 1845. Documents inédits avec introduction et commentaires (Casablanca: Kaganski, 1947), 13-14.

8 The previous two paragraphs are a brief summary of my book Snouck Hurgronje en de Islam. Acht artikelen over leven en werk van een oriëntalist uit het koloniale tijdperk (Leiden, 1987), 
Seventy-five years after his death, it seems quite clear that Snouck's major historical influence lies in his contributions to the formation of a colonial Islam policy in the Dutch East Indies. The Republic of Indonesia became the direct heir of the Dutch East Indies as they had been created and forged into one national state from innumerable smaller political entities during the colonial era. Similarly, the Dutch East Indian Islam policies, as well as the institutions developed for them during the colonial period, became the basis of the Islam policies of the Republic of Indonesia after its independence. Jakarta's Ministry of Religious Affairs, for instance, is a direct continuation of the "Office of Religion" or Kantor Agama of the colonial era. ${ }^{9}$ From this perspective, Snouck's Muslim network can be expected to shed light on the colonial prehistory of modern Indonesia, and especially on the origin of its Islamic policies and their related institutions. As Snouck's personal archives are now becoming accessible at Leiden University Library, also in digitalized form, this is the right time for a first exploration of at least the key people in his extensive Muslim network.

Here, one should separate the numerous incidental contacts on the one hand from the much less numerous long lasting contacts, on the other hand. In the many official capacities he occupied: Advisor of Islamic and Native Affairs, first in the Dutch East Indies and later in the Netherlands; Professor of Arabic and Islamic Studies at Leiden University; editor of the Encyclopaedia of Islam published at Brill; Supervisor of the Oriental Manuscripts Collection of the Leiden University Library with the title "Interpres Legati Warneriani"; president of the Dutch Oriental Society—in all these official capacities Snouck was likely to be approached from many sides by people with some specific interest. In the present context we focus exclusively on those long lasting Muslim contacts that occupied a structural place in his biography.

The historical basis of Snouck's Muslim network was certainly his journey to Mecca in the years 1884 and 1885 and his "temporary conversion" to Islam. Towards his European network, Snouck was crystal-clear in "defending" his conversion as a mere instrument to obtain access to Mecca and be accepted in a Muslim society. For instance, in a contemporary letter, dated Mecca, 1 August

292 pp. with bibliography. This book contains a (slightly) revised version of eight articles published in various periodicals between 1980 and 1987. See also the Indonesian edition of this book, Snouck Hurgronje dan Islam. Delapan karangan tentang hidup dan karya seorang orientalis zaman kolonial (Jakarta: Girimukti Pasaka Publishers, 1989), 312 pp.

9 Compare the work of Moch. Nur Ichwan, "Official Reform of Islam: State Islam and the Ministry of Religious Affairs in Contemporary Indonesia, 1966-2004" (PhD diss., Tilburg University, 2006). 
1885, he assured his former teacher, the German orientalist Theodor Nöldeke, that he regularly visited the Kaba, because one could not live in a Muslim society without outwardly behaving as a Muslim, "because the days when Christians or any other scum could live here in freedom, belong to the past."10 And in a later letter to the same teacher, of 27 February 1915, Snouck justifies his Islam as follows:

No, my izhâr al-islâm [my outward Islamic behavior] has nothing in common with the theory that in war all means are permitted. The former is an intransitive measure [i.e., a measure without an object] that in the worst case could harm him who applied it. A measure, in my eyes far more innocent than when one, in a modern society, would partake of the sacraments of a church or desire them for one's children, without attaching to them any value. It is that, which I consider personally as blasphemy, but not the accommodation to the externals of an intellectually inferior society which are necessary in order to be considered there as a human being.... I would regard a similar accommodation to Christian ritual as self-evident in the society of South-African Boers, who also mistrust someone standing outside their religious community and regard him as a wretch. ${ }^{11}$

On another occasion, Snouck referred to his "temporary conversion" in a more indirect way, as follows: "By having studied the theory of Mohammedan law and doctrine and prepared myself for entire accommodation to the practice of Mohammedan manners and customs I was able to 'hide in the full light' as a proverbial saying of Java has it, to constantly observe without being regarded as observer."12 Snouck's own explanations of his Islam towards his European network and his European audience are consistent and fit into the social and political realities of his time. I see no reason to doubt their sincerity. However, a different view was proposed by Jan Just Witkam, who argued that the sincerity of Snouck's Islamic faith cannot be judged scientifically, but must remain a matter between him and his Creator. ${ }^{13}$ But this view is contradicted by Snouck's

10 C. Snouck Hurgronje, Orientalism and Islam: The Letters of C. Snouck Hurgronje to Th. Noldeke from the Tübingen University Library (Published by P.S. van Koningsveld, Leiden, Faculty of Theology, 1985), 8.

11 Snouck Hurgronje, Orientalism and Islam, 222.

12 Snouck Hurgronje, C. "Some of my Experiences with the Muftis of Mecca," in Jaarverslagen 1934-1940 van het Oostersch Instituut Leiden (Leiden, 1941), 4.

13 C. Snouck Hurgronje, Mekka, vertaald en ingeleid door Jan Just Witkam (Amsterdam: Atlas, 2007), especially $75 \mathrm{ff}$. 
own numerous and crystal-clear explanations towards his European network, as well as by his consistent agnostic convictions that are transparent on many pages of his publications throughout his life.

From the Muslim side, Snouck's conversion to Islam was accepted as genuine and sincere, right from the beginning, by some circles at least. When Snouck, after his expulsion from Mecca, feared that mistrust of his conversion might have been a cause, an Algerian acquaintance, 'Azīz b. Ḥaddād, assured him that this was not the case, as "you have publicly announced your conversion to Islam and even the religious scholars of Mecca testified to that" ("li-annaka ashharta islāmaka wa-'ulamā’u Makka yashhadūna bi-dhālika")..14 In certain circles, however, Snouck's conversion became controversial. The famous Egyptian reformist, Muhammad Rashīd Riḍa, for instance, once spoke of Snouck as "an enemy of Islam and a hypocrite who [falsely] pretended to have converted to Islam and had called himself 'Abd al-Ghaffär; he stayed for a while in al-Azhar and went to Mecca where he resided to spy on the Muslims."15 (The episode in al-Azhar is historically incorrect. Riḍā may have confused Snouck with Ignaz Goldziher, who studied for some time in al-Azhar, but without a prior conversion.) Yet, according to the following Muslim personalities and groups who occupy places of pride in his Islamic network, Snouck's conversion was accepted as genuine and sincere.

al-Sayyid ‘Abdallāh b. Muḥammad b. Ṣâliḥ al-Zawāwī (d. 1924)

One highly influential scholar who consistently confirmed and defended the authenticity of Snouck's Islam until his death in 1924, was the Meccan scholar Sayyid 'Abdallāh b. Muḥammad b. Ṣālih al-Zawāwī whom Snouck met in 1884 in Jeddah for the first time, even before entering the city of Mecca. Snouck followed his courses in the Holy City and stayed in contact with him after that. Many years later, after the Turkish revolution and in the period of the rule of Sharif Husayn in Mecca, he was appointed to the highest positions a religious scholar could occupy in Mecca, viz. of Shafi'i mufti and Shaykh al-'ulamä'. It was the already-quoted Rashīd Riḍā, who in an article in his Majallat al-manār acknowledged that "my friend 'Abdallāh al-Zawāwī, the mufti of Mecca, who

\footnotetext{
14 Letter dated 20 Dhū l-Qa'da 1302 (31 August 1885) in the Leiden University Library in portfolio $\mathrm{S}_{32}$ of Cod. Or. 18097, among the Snouck Hurgronje documents transferred from the former Oosters Instituut.

15 M. Rashīd Riḍā, "Ḥālat al-muslimīn fì Jāwa wa-l-iṣlāḥ," al-Manār 14 (1911), 761-767.
} 
was one of his [=Snouck's] teachers, believed in the genuineness of his conversion to Islam." 16

According to some contemporary printed Arabic sources, al-Zawāwī had been expelled from Mecca in the year 1307/1889-189o by Sharif 'Awn because of a conflict that had arisen between them concerning the authenticity of Snouck's conversion to Islam, which Sharīf 'Awn doubted, but al-Zawāwī defended. According to these sources, this forced al-Zawāwi to travel to Java (the Dutch East Indies), Malaysia, China, Japan, and India.. ${ }^{17}$ For his part, Snouck Hurgronje informs us that al-Zawāwī's

intimate connections with Turkish governors and with members of the Sherif family who disliked the Grand Sherif Aun, became ever more evident, so that the latter watched a favourable opportunity to get rid of his opponent. Well knowing that such an opportunity could not fail to come, Sayyid Abdallah secretly put his private affairs in order, and escaped from his birthplace in woman's garb. For about fourteen years his life was that of a wandering scholar; he visited his numerous friends and pupils in British India, in the Straits Settlements, in the Dutch Indies, where we often met. Wherever he came he was gladly received and entertained by his admirers, who in the meantime asked him for fatwâ's on questions of law, and for a couple of years he acted as the official Mufti of the Sultan of Pontianak in Borneo, a prince of Arabic descent. ${ }^{18}$

The extensive collection of al-Zawāwī's Arabic letters to Snouck preserved in Leiden is an eloquent witness of their continuous contacts. These letters were written from different places where al-Zawāwī was staying, among others during his journeys in Southeast Asia: Singapore, Pontianak, Sukabumi, Yokohama, Calcutta, etc. In all of his letters (written in Arabic) which span the period 1894-1917, Snouck is addressed as "Hājjī 'Abd al-Ghaffār [Effendi], may God preserve him" (al-Hājj 'Abd al-Ghaffār [Effendi] hafizahu Alläh), preceded by various expressions of politeness and appreciation..$^{19}$ In 1908, after the Turkish revolution, he returned to Mecca. In addition to the offices of Shafi'i mufti and

16 Rashīd Riḍā, M. "Fatāwī al-Manār (Masāil al-libās wa-l-zayy)," al-Manār 26 (1926), 416-424.

17 Aḥmad Shiryāf, "al-Sayyid 'Abdallāh b. Muḥammad Ṣālị̣ al-Zawāwī Muftī l-Shāf'iyya biMakka," Majallat al-Sāda al-Ashräf, vol. 11 (without pagination), and the sources mentioned there: http://www.alashraf.ws/vb/showthread.php?t=46218.

18 Snouck Hurgronje, "Some of my Experiences," $15 \mathrm{f}$.

19 Leiden University Library, Cod. Or. 8952 A: 1117-1127. 
Shaykh al-'ulamā', he occupied the posts of Ra'īs Majlis al-Shūra, and that of Ra'îs Majlis al-Shuyūkh, thus playing a major political role in the period preceding the Saudi era. He was shot in Ta'if in 1924.

\section{Raden Aboe Bakar Djajadiningrat (ca. 1854-1914)}

A key person of an entirely different nature was Raden Aboe Bakar, scion of the noble Javanese family of Djajadiningrat, who became Snouck's personal assistant in Arabia and afterwards. Raden Aboe Bakar had studied for five years under the guidance of 'Abdallāh al-Zawāwī, before he became Snouck's personal "research-assistant." He collected most of the vital information about the Jawi community in Mecca and about Meccan manners and customs which were to form the backbone of Snouck's book on Meccan life in the late nineteenth century. His field work notes are preserved in Leiden. ${ }^{20}$

At Snouck's personal recommendation, Raden Aboe Bakar was officially connected to the Dutch consulate in Jeddah as translator and information officer who, among others, was to provide the Dutch consul with information needed about the Jawi (i.e., Dutch Indian) community in Mecca.

What had made him so employable was his family connections with the Dutch administration in West Java, his connections with the large Jawi community in Mecca, and his fluency in several languages required for dealing with them, namely Arabic, Malay, Sundanese, and Javanese. From then on he served as the leading "native" hand at the consulate, liaising between the Dutch consul and the local authorities, both Ottoman and Sharifan; translating for visiting pilgrims from the Dutch Indies when they called in to register their arrival; and monitoring the activities of the Jawi community in nearby Mecca. ${ }^{21}$

Aboe Bakar was personally involved in preparing Snouck for his conversion to Islam in 1884 , and his letters dating back to the period 1885 to $1912^{22}$

\footnotetext{
20 See my Snouck Hurgronje en de Islam, index s.v. Djajadiningrat, Raden Hadji Aboe Bakar.

21 Michael F. Laffan, Raden Aboe Bakar, "An Introductory Note Concerning Snouck Hurgronje's Informant in Jeddah (1884-1912)," Bijdragen tot de Taal-, Land- en Volkenkunde 155 (1999): 517-542; idem, "Writing from the Colonial Margin. The Letters of Aboe Bakar Djajadiningrat to Christiaan Snouck Hurgronje," Indonesia and the Malay World $3_{1}$ (2003), $35^{6}-380$, especially $35^{8}$.

Leiden University Library, Cod. Or. $895^{2}$ A: 9-13.
} 
witness his conviction of the authenticity of Snouck's Muslim identity; he addressed him, among other titles, as "our brother in God Shaykh 'Abd al-Ghaffār Effendi, may God favor him in both worlds" ("al-Salāmu 'alaykum wa-rahmat Allāh wa-barakātuhu bi-l-dawām 'alā mamarr al-layāli wa-layyām-yukhașșu bi-hadhā ilā hadrat sa'ādat al-'azizz dhī l-majd al-rahīb al-adīb akhīnā fì Allāh al-shaykh 'Abd al-Ghaffār Effendi ballagha Allāhu manānahu fi l-dārayn") (1885). At times, the letters seem to express the subordinate affection of a disciple or of a servant towards his master: "His Highness, the unique person of his age, my fountain-head the great scholar 'Abd al-Ghaffār" ("Haḍrat farìd 'așrihi manbatī l-alläma 'Abd al-Ghaffār") (1891), and, in 1897: "His Highness, the most exemplary model, my highest support Dr 'Abd al-Ghaffār, may his rank be increased" ("Hadrat qudwat al-amāthil 'umdatī l-a'à Dr 'Abd al-Ghaffār zìda qadruhu"), in 1905: "The most exemplary model, his Excellency 'Abd al-Ghaffär, may his wishes continue to be fulfilled" ("Qudwat al-amāthil sa'ādatlu 'Abd al-Ghaffār dāma kamā rāma"; and, finally, in 1909, "Haḍrat 'azizzì l-mufakhkham al-'allāma Dr C. Sn. 'Abd al-Ghaffär Effendì dāma kamā rāma").

In the eyes of a close friend like Raden Aboe Bakar, Snouck's Islam was an indisputable and, of course, also a public fact. By his close connections to Snouck in Arabia and his family connections in circles close to Snouck's women in Java, Raden Aboe Bakar was also informed in detail about Snouck's intimate life in Arabia and Java, including his women and children.

A young West Javanese religious scholar Snouck met in Mecca also played a major role during the remaining period of Snouck's life. First of all, during his seventeen-year stay in the Dutch East Indies, he assisted him, among others, during his field research in the pesantrens or religious schools in Java during the early years of his stay, as well as during his following field research in Acheh. Both research projects resulted in reports with a major influence on Dutch colonial policies. I am referring to the West Javanese scholar Ḥajjī Ḥasan Muștafā, who was in his early forties when he met Snouck (then twenty-eight years old) in Mecca. Hâjjī Hasan had already returned to his country of origin when Snouck joined him in the Dutch East Indies, in 1889.

At my proposal, H. Hasan Moestapha accompanied me in the years 1889-1891 during some of my journeys through Java, and for an important part I owed it to his inappreciable support that I soon was surrounded by 
a wide circle of Natives from the contacts with whom I soon was able to draw the necessary information. ${ }^{23}$

These are Snouck's own words, in appreciation of his friend.

Haajjī Hasan Muștafā was appointed chief penghulu [judge] of Kotaradja in Acheh (North Sumatra) in 1892, at Snouck's recommendation, and regularly reported to Snouck about relevant political and military developments in Acheh, as is witnessed by a bundle of his letters, usually written from Acheh in Arabic to Snouck. ${ }^{24}$ At his request, Ḥasan Muștafā was transferred to the chief penguluship in Bandung some years later, again at the proposal of Snouck. Ḥasan Muștafā was a gifted writer on Sundanese manners and customs, as well as a composer of Sundanese poetry.

Hasan Muștafâ's close contacts with Snouck became the object of polemical articles in the Arab press. A long article in the Cairo weekly Misbāh al-Sharq (29 November 1902, No. 232), written by "one of the prominent Muslims in the lands of Jāwah," asserted, among other issues, that the Dutch government was using the services of Hâajjī Ḥasan Muștafā in order to persuade the local population to leave Islam and embrace Christianity. According to this article, Hasan Mușțafā was spreading various heresies among the people of the villages of West Java, acting under the direct influence of Snouck Hurgronje by whom he was protected personally.

As we shall see later on, Hasan Muștafā was personally involved in arranging both Snouck's Islamic marriages to daughters of the West Javanese nobility. After Snouck left the Dutch East Indies, Ḥasan Mușțafā regularly informed him about his five children whom he had left behind in Java, together with his second wife. An extensive collection of his letters from this period is preserved in Leiden as well. In these letters, Ḥasan Mușțafā usually avoided mentioning Snouck's name in a direct manner, in accordance with Sundanese etiquette. They nevertheless reflect their intimate, affectionate relationship in which the shared Islamic faith is presupposed. This is witnessed by the addresses of his letters: "Peace be upon you and God's blessings" ("al-Salāmu 'alaykum wa-rahmat Allāh wa-barakātuhu") or "Peace be upon us and upon the pious servants of God" ("al-Salāmu 'alaynā wa-'alā 'ibād Allāh al-șāliḥin"); and elsewhere:

23 C. Snouck Hurgronje, Ambtelijke Adviezen van C. Snouck Hurgronje 1889-1936. Uitgegeven door E. Gobée en C. Adriaanse ('s Gravenhage: Nijhoff, 1957-1965), 1:180. See also P.S. van Ronkel, "Aanteekeningen over Islam en folklore uit het reisjournaal van Dr C. Snouck Hurgronje," Bijdragen Koninklijk Instituut (1942), 311-339.

24 Leiden University Library, Cod. Or. 18097, Portfolio 16. 
Peace be upon you and God's mercy and blessings. To the point now: We already sent you a picture, as a token of friendship and to wish you a happy feast and a feast of those who (by their growing age) repeatedly celebrate it. Therefore, may you and I belong to those accruing and gaining benefits, one year after another, years after years belonging to those who are respected (by men) and accepted (by God). Amen. ("al-Salämu 'alaykum wa-raḥmatAllāhwa-barakātuhu.Ammāba'du:fa-qadșadarat li-janābikum minnā al-șāra wa-l-șāra tahnia wa-mu'ānasa bi-al-ìd al-saìd wa-ìd

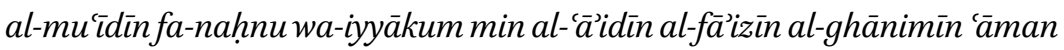
ba'da 'ām, sinīna ba'da sinìn min al-muhtaramin al-maqbütīn, Amīn." $)^{25}$

\section{Sayyid 'Uthmān b. 'Aqīl al-'Alawī (1822-1914)}

At the very center of the key people of Snouck's Muslim network stood the well-known Arab scholar of South Arabian (Hadhramī) origin Sayyid 'Uthmān b. 'Abdallāh b. 'Aqīl b. Yahyā l-'Alawī (1822-1914) of Batavia. From 1889, the year of Snouck's arrival in the Dutch Indies, he was active in the colonial administration (from 1891 in the official capacity of "Honorary Adviser for Arab Affairs"). ${ }^{26}$ Sayyid 'Uthmān's grandfather 'Aqīl had been the head of the Husaynī sayyids in Mecca. He was killed around the year $185^{\circ}$ in the prison of the Grand Sharif of Mecca. Sayyid 'Uthmān himself was born in Batavia, but spent a good part of his youth in Hadramawt and in Mecca. Both in his country of origin and in Mecca he had studied under the most famous teachers. After returning to Java, he gave courses in Islamic jurisprudence and theology in the city of Batavia.

25 The letters dating from the period $1894^{-1911}$ are in Leiden University Library, Cod. Or. $895^{2} \mathrm{~A}, 713$, and $735^{-} 738$.

26 There are many references to the life and work of Sayyid 'Uthmān in Snouck Hurgronje's works. See the indices of his Verzamelde Geschriften en his Adviezen. In recent years, several articles were published on aspects of his biography, among which I mention here Azri Azyumardi, "A Hadhrami Religious Scholar in Indonesia: Sayyid 'Uthmân," in Hadhrami Traders, Scholars and Statesmen in the Indian Ocean 1750s-196os, ed. U. Freitag and W.G. Clarence-Smith (Leiden: Brill, 1997), 249-263. N.J.G. Kaptein, "Arabophobia and Tarekat: How Sayyid 'Uthmân Became Advisor to the Netherlands Colonial Administration," in The Hadhrami Diaspora in Southeast Asia: Identity Maintenance or Assimilation?, ed Ahmed Ibrahim Abushouk, Hassan Ahmed Ibrahim (Leiden/Boston: Brill, 2009), 33-44. Recently, N.J.G. Kaptein published his biography of Sayyid 'Uthmān, entitled Islam, Colonialism and the Modern Age in the Netherlands East Indies: A Biography of Sayyid Uthman (1822-1914) (Leiden: Brill, 2015), containing a special chapter on Sayyid 'Uthmān's relations with Snouck Hurgronje (103-140). 
Sayyid 'Uthmān was a gifted and highly productive scholar who published an extensive series of smaller writings, especially fatwās, on his own lithographic press. Snouck Hurgronje regularly relied upon him in many of his advices to the colonial authorities. He occasionally referred to these materials in his published studies, in which he discussed his views on various aspects of modernity and the use of modern techniques in a religious context, for instance on the use of the phonograph for registering and reproducing recitals of the Qurān.

Innumerable times, Sayyid 'Uthmān proved his use as an ally of the Dutch East Indian government, among others when he passed on to Snouck in 1894 a fatwa of the mufti of Johor. In it, the mufti proved from Islamic sources that the Achehnese should stop fighting against the Dutch, because of the great damage that would be done to Islam and Muslims if they continued the war. ${ }^{27}$ Sayyid 'Uthmān's staunch support of Dutch rule comprised, among others, the text of a supplication or $d u^{\prime} \bar{a}^{\prime}$ composed by him for the Dutch Queen Wilhelmina at the occasion of her eighteenth birthday, when she was able to relieve her mother, the Queen Mother Emma, who had acted as her regent of the Dutch Empire. ${ }^{28}$ This prayer was to be read in all the mosques of the Dutch East Indies. It in fact provoked extensive polemical reactions. It is not surprising that the Egyptian reformist Rashīd Ridā incidentally found occasion to criticize Sayyid 'Uthmān as an opponent of his reforms. ${ }^{29}$

Sayyid 'Uthmān's letters to Snouck in Leiden date back to the years 1886 and 1888, shortly after Snouck's return to the Netherlands from Arabia. In these earliest letters, he addresses Snouck as "Mister Snouck Hurgronje" ("al-Khawāja Snouck Hurgronje") (1886) and as "Dr Snouck Hurgronje" ("al-Duktūr Snouck Hurgronje"). In these earliest letters he draws Snouck's attention to his own publications and to the place of authority he occupies among the native Muslims in Jāwa who consult him in their religious and legal difficulties. He refers to the assistance he occasionally lent to the Dutch authorities when they wanted to investigate the mystical brotherhoods, and asks Snouck to recommend him for the official position of advisor or "mufti." As we saw earlier, after Snouck's arrival in the Indies, in 1889, Sayyid 'Uthmān in fact did become his right hand, in the position of "Honorary Advisor of Arab Affairs."

27 Sālim b. Aḥmad b. Muḥsin b. Bū Bakr al-'Ațțās, Risālat al-taslīm wa-l-qitāl wa-l-radd 'alā man aftā bi-ghayri istidlāl, privately owned manuscript in the Netherlands. A photocopy is in the possession of the present author.

28 A full study is provided by Nico J.G. Kaptein, "The Sayyid and the Queen: Sayyid 'Uthmân on Queen Wilhelmina's Inauguration on the Throne of the Netherlands in 1898," Journal of Islamic Studies 9, no. 2 (1998): 158-177.

Rashīd Rị̣ā, "Ḥālat al-muslimīn fĩ Jāwa." 
When Snouck returned to Leiden, and thus after having known him personally for many years in the Dutch East Indies, Sayyid 'Uthmān addressed him as follows: "His Highness, the venerable, most beloved and profound friend Professor 'Abd al-Ghaffār, may his fame and honor endure, his days be fruitful and the signs (of his prestige) be advanced. Amen" ("Hadrat al-mukarram al-muhibb al-adwam wa-l-șăhib al-aḥkam al-Profisūr 'Abd al-Ghaffār dāma 'izzuhu wa-ïlāluhu wa-țābat ayyāmuhu wa-àlà a'lāmuhu-Aminn") (1906), and in 1909 as follows:

I convey many greetings and express deep appreciation (informing you that there is nothing like the longing to see a noble friend, for whom there is no substitute), to his Esteemed Highness, both in essence and in properties, our beloved companion Professor 'Abd al-Ghaffār, may his honor endure and his rank be increased, and his prestige raise high in regions zand cities ("Ahdī al-salām al-jazìl wa-l-thanā' al-jamül (ma'a al-inbä' bianna al-shawq ilā ru’yat al-ṣadìq al-nabìl laysa lahu mathïl haythu lam yūjad lahu badīl) ilā hạdrat al-aziz dhātan wa-șifātan muhibbinā wa-anisinā al-Profisūur 'Abd al-Ghaffār; dāma izzuhu wa-zīda qadruhu wa-'alā șìtuhu fíal-aqțār wa-al-amșār").

A selective analysis of the key persons of Snouck's Muslim network must pay some special attention to the role of women in Snouck's life in Mecca and the Dutch East Indies. As we presently see, these women are likely to have strengthened his social position considerably.

During his stay in Mecca, Snouck succeeded in buying an Ethiopian slave girl with whom he lived together and to whom he incidentally referred as his "family" (between inverted commas) and whose name has remained unknown, so far. Snouck praised her, among others, by stating that "fortunately she does not show any of the unpleasant peculiarities of which her race is sometimes accused. It is a fact," Snouck continued,

30 The contents of this paragraph are a brief extract of the more extensive data provided in my book Snouck Hurgronje en de Islam, especially Ch. 5, 131-142, mainly based on my interviews of Snouck's descendants in Bandung, in January 1983. The extract is preceded by the new information concerning Snouck's Ethiopian slave girl in Mecca, which was provided for the first time by Jan Just Witkam, in the introduction to his Dutch translation of Snouck's Mekka (2007). 
that the experts here prefer the good Abyssinian girls over the daughters of the people [of Mecca], to the great irritation of the latter. From my part, I decided to follow this example mainly because each day my knowledge about the excessive demands and the devilish tricks of the daughters of the Holy City is increased, and also because I am able to inform myself about their life and customs without involving myself into more intimate ties with them.

In the Dutch East Indies, many Dutchmen lived with indigenous concubines. Their mixed descendants constituted the specific social group of the so-called "Indos." Often, a Dutchman would leave his concubine with their children behind in the Dutch Indies, when, at the completion of his service, he repatriated to the Netherlands. The case of Snouck's Islamic marriages with daughters of the Javanese aristocracy was different in some important aspects, but similar in other aspects. Shortly after his arrival in Java, he married the daughter, Sangkana, of the local chief panghulu (or chief $q \bar{a} d \underline{\imath} \bar{c}$ ) of Ciamis, Raden Hājjji Muhammad Țāib. She gave him four children, Salmah Emah, Oemar, Aminah, and Ibrahim. She died in 1896, when she had a miscarriage of a fifth child. Press articles that soon appeared in Dutch Indian newspapers of early 1890 accused Snouck of cheating the local population and demanded appropriate measures from the government. These articles stated that the marriage had been concluded in the Friday Mosque of the town. Snouck denied the reports in writing, as did the governor general of the Dutch East Indies.

A second Islamic marriage was concluded by Snouck in 1898, with Siti Sadijah, then thirteen years old, the only daughter of Raden Ḥajjī Muhammad Soeèb, vice-panghulu at Bandung, who was known, among others things, as a gifted reciter of the Quraan on Id al-Fițr in its Friday Mosque. From this marriage was born one son, Joesoef, in 1905, whom I visited in Bandung in the 1980s. He confided to me the story of Snouck's Muslim families, which, until then, had been kept strictly secret in the Netherlands. When Snouck left for the Netherlands in 1906 he had made financial arrangements for the maintenance of his children and second wife, while Ḥājjī Ḥasan Muștafāa, who had been the marriage-maker in both cases, kept an eye on them and informed Snouck about their vicissitudes.

\section{Conclusion}

Snouck's conversion of convenience was perhaps the most successful case in colonial history of the instrumentalization of Islam for the benefit of the 
Islamic policies of the rulers and for the development of ethnological field studies. The second volume of Snouck's book on Mecca, dealing with the daily life of Mecca, could not have been completed without it, even though much of the data were gathered after his departure from the Holy City by his assistant Raden Aboe Bakar. Snouck's major books on the Achehnese as well as the Gayonese, could not have been written without the advantages of his conversion, neither could he have given the great majority of his advice to the colonial government. The key people of his Muslim network, each in their own sphere of influence, contributed considerably, not only in establishing and consolidating his social position within Muslim circles, but they also contributed to his authority among Muslims of the Indonesian archipelago at large. He soon acquired the prestige of a Muslim religious scholar himself. Whoever understands the social impact of a network like that of Snouck cannot be surprised at all to find petitions in his archive addressed to him in Batavia as "the Mufti of Batavia," "Muftĩ Jāwa" (= the mufti of the Dutch Indies), and even as "Shaykh al-Islām fì l-Diyār al-Jāwiyya."31 All of these addresses are reflections of the widespread recognition of Snouck as a Muslim and indeed as a Muslim scholar, as sanctioned by a wide range of Muslim scholars of the highest rank.

\section{Bibliography}

\section{Archival Sources}

Leiden University Library, Cod. Or. 8952A: Private Letter Archive of Snouck Hurgronje. All documents referred to from this archive in the present article are now online and accessible through the catalogue of the Leiden University Library.

Leiden University Library, Cod. Or. 18097: Archive of Snouck Hurgronje, in 65 portfolios. Documents referred to from this archive in the present article are not (yet) accessible online.

\section{Secondary Sources}

Abdel Razaq, Salah. Neo-Muslim Intellectuals in the West and Their Contributions to Islamic Thought and the Formation of Western Islam: An Exploratory Investigation of the Religious and Literary Activities of Western Neo-Muslim Intellectuals. Leuven: Peeters, 2008.

31 Leiden University Library, Cod. Or. 18097, Portfolio 1. 
Azyumardi, Azri. "A Hadhrami Religious Scholar in Indonesia: Sayyid 'Uthmân." In Hadhrami Traders, Scholars and Statesmen in the Indian Ocean 1750s-196os, edited by U. Freitag and W.G. Clarence-Smith, 249-263. Leiden: Brill, 1997.

Bennassar, Bartolomé and Lucile Bennassar. Les chrétiens d'Allah. L'histoire extraordinaire des rénégats. XVIe-XVIIe siècles. Paris: Perrin, 1989.

Caillé, Jacques. Une mission de Léon Roches à Rabat en 1845. Documents inédits avec introduction et commentaires. Casablanca: Kaganski, 1947. (= « Publications de l'Institut des Hautes-Etudes Marocaines », tome 43).

Kaptein, Nico J.G. "Arabophobia and Tarekat: How Sayyid 'Uthmân Became Advisor to the Netherlands Colonial Administration." In The Hadhrami Diaspora in Southeast Asia: Identity Maintenance or Assimilation?, edited by Ahmed Ibrahim Abushoul, Hassan Ahmed Ibrahim, 33-44. Leiden/Boston: Brill, 2009.

Kaptein, Nico J.G. Islam, Colonialism and the Modern Age in the Netherlands East Indies: A Biography of Sayyid 'Uthman (1822-1914). Leiden/Boston: Brill, 2014.

Kaptein, Nico J.G. "The Sayyid and the Queen: Sayyid 'Uthmân on Queen Wilhelmina's Inauguration on the Throne of the Netherlands in 1898." Journal of Islamic Studies 9, no. 2 (1998): 158-177.

Koningsveld, P.S. van. Snouck Hurgronje en de Islam. Acht artikelen over leven en werk van een oriëntalist uit het koloniale tijdperk. Leiden, 1987.

Koningsveld, P.S. van. Snouck Hurgronje dan Islam. Delapan karangan tentang hidup dan karya seorang orientalis zaman kolonial. Jakarta: Girimukti Pasaka Publishers, 1989.

Kramer, Martin. "The Road from Mecca: Muhammad Asad (born Leopold Weiss)." In The Jewish Discovery of Islam, edited by Martin Kramer, 225-247. Tel Aviv: Tel Aviv University, 1999 .

Laffan, Michael F. "Raden Aboe Bakar: An Introductory Note Concerning Snouck Hurgronje's Informant in Jeddah (1884-1912)." Bijdragen tot de Taal-, Land- en Volkenkunde 155 (1999): 517-542.

Laffan, Michael F. "Writing from the Colonial Margin. The Letters of Aboe Bakar Djajadiningrat to Christiaan Snouck Hurgronje." Indonesia and the Malay World 31 (2003): $35^{6-380 .}$

Ludovico di Varthema. The Itinerary of Ludovico di Varthema of Bologna from 1502 to 1508 as Translated from the Original Italian Edition of 1510, by John Winter Jones, F.S.A. in 1863 for the Hakluyt Society. London: Argonaut Press, 1928.

al-Mayurqī', 'Abdallāh al-Tarjumān. Tuhfat al-arīb fíl-radd 'alā ahl al-șalīb. Edited and translated by Mikel Epalza. Madrid: Hiperión, 1994.

Nur Ichwan, Moch. "Official Reform of Islam: State Islam and the Ministry of Religious Affairs in Contemporary Indonesia, 1966-2004." PhD dissertation, Tilburg University, 2006.

Rashīd Riḍā, M. "Fatāwī al-Manār (Masāill al-libās wa-l-zayy)." al-Manār 26 (1925), 416-624. 
Rashīd Rị̣ā, M. "Hālat al-muslimīn fī Jāwa wa-l-ișlāḥ." al-Manār 14 (1911), 761-764.

Ronkel, P.S. van. "Aanteekeningen over Islam en folklore uit het reisjournaal van Dr C. Snouck Hurgronje." Bijdragen Koninklijk Instituut (1942), 311-339.

Sālim b. Aḥmad b. Muḥsin b. Bū Bakr al-'Aț̣āas. Risālat al-taslīm wa-l-qitāl wa-l-radd 'alā man aftā bi-ghayri istidlāl. Privately owned manuscript. A photocopy is in the possession of the present author.

al-Samhūdī. Wafā l-wafā̀ bi-akhbār dār al-Muștafā. Edited by Qāsim al-Sāmarrāīi 5 vols. Mecca/Medina: Mu'assasat al-Furqān, 1422/2001.

Shiryāf, Aḥmad. al-Sayyid 'Abdallāh b. Muḥammad Șālị̣ al-Zawāwī Muftī l-Shāfi'iyya bi-Makka. Majallat al-Sāda al-Ashrāf, vol. 11. Available online: http://www.alashraf .ws/vb/showthread.php? $\mathrm{t}=46218$.

Snouck Hurgronje, C.- Ambtelijke Adviezen van C. Snouck Hurgronje 1889-1936. Uitgegeven door E. Gobée en C. Adriaanse. 3 vols. 's Gravenhage: Nijhoff, 1957-1965 ('s Rijks Geschiedkundige Publicatiën 33-35).

Snouck Hurgronje, C. Mekka vertaald en ingeleid door Jan Just Witkam. Amsterdam: Atlas, 2007.

Snouck Hurgronje, C. Orientalism and Islam: The Letters of C. Snouck Hurgronje to Th. Noldeke from the Tübingen University Library. Published by P.S. van Koningsveld. Leiden, Faculty of Theology, 1985.

Snouck Hurgronje, C. "Some of my Experiences with the Muftis of Mecca." In Jaarverslagen 1934-1940 van het Oostersch Instituut Leiden. Leiden, 1941. 